\title{
PEMBERDAYAAN PEMUDA KARANG TARUNA KELURAHAN SETU MELALUI PELATIHAN PEMELIHARAAN SEPEDA MOTOR
}

\author{
Ismojo $^{2)}$, Singgih Hartanto ${ }^{2)}$, Matsuani $^{3)}$, J. Victor, T. $^{4)}$ \\ ${ }^{1}$ Teknik Mesin Otomotif Dip. III, Institut Teknologi Indonesia (ITI), email: ismojo@iti.ac.id \\ ${ }^{2}$ Teknik Mesin Otomotif Dip. III, Institut Teknologi Indonesia (ITI), email: singgih.hartanto@iti.ac.id \\ ${ }^{3}$ Teknik Mesin Otomotif Dip. III, Institut Teknologi Indonesia (ITI), email: Matsuani@iti.ac.id \\ ${ }^{4}$ Teknik Mesin, Institut Teknologi Indonesia (ITI), email: jvictor.tuapetel@iti.ac.id
}

\begin{abstract}
Abstrak
Menurut Dinas Ketenagakerjaan Kota Tangerang Selatan (2019) tercatat angka pengangguran mencapai 40 ribu. Dari jumlah tersebut, lulusan SMA/ SMK mendominasi angka pengangguran warga Kota Tangerang Selatan. Berbagai upaya mengatasi masalah tersebut telah dilakukan, diantaranya memberikan pelatihan untuk meningkatkan kompetensi dan ketrampilan pemuda lulusan SMA/ SMK. Kegiatan Abdimas ini bertujuan untuk melatih pemuda Karang Taruna di Kelurahan Setu, Kota Tangerang Selatan dengan memberikan pengetahuan dan meningkatkan ketrampilan dalam pemeliharaan/servis kendaraan sepeda motor. Kegiatan pelatihan dilaksanakan di Bengkel Otomotif, Prodi Teknik Mesin Otomotif, Institut Teknologi Indonesia selama 4 (empat) hari yang diukuti oleh 7 orang peserta. Materi yang diberikan meliputi teori dan praktek. Metode pelatihan menggunakan pendekatan pendidikan orang dewasa, peserta pelatihan belajar secara aktif, sedangkan pelatih/ instruktur lebih banyak berperan sebagai fasilitator. Hasil kegiatan selama 4 (empat) hari, peserta cukup menguasai pengetahuan dan praktek pemeliharaan kendaraan sepeda motor. Dari kegiatan pelatihan ini diharapkan peserta memiliki kepercayaan diri dan daya saing dalam mendapatkan pekerjaan atau membangun kewirausahaan bisnis bengkel yang masih memiliki peluang bisnis yang prospektif di wilayah Kota Tangerang Selatan.
\end{abstract}

Kata kunci: pengangguran lulusan SMA/SMK, pelatihan, perawatan, sepeda motor

\begin{abstract}
According to the South Tangerang City Manpower Office (2019) the unemployment rate reached 40 thousand. Of these, high school / vocational school graduates dominate the unemployment rate of residents of South Tangerang City. Various efforts have been made to overcome these problems, including providing training to improve the competencies and skills of high school / vocational high school graduates. This Community Service Program aims to train Youth organization in Setu Village, South Tangerang City, providing knowledge and improving skills in motorcycle vehicle maintenance and service. The training activities were carried out at the Automotive Workshop, Automotive Engineering Study Program, Indonesian Institute of Technology for 4 (four) days, followed by 7 participants. The material provided includes theory and practice. The training method uses an adult education approach, trainees learn actively, while the trainer / instructor plays a more facilitating role. The results of the activity for 4 (four) days, the participants were sufficient to master the knowledge and practice of motorcycle maintenance. From this training activity, participants are expected to have confidence and competitiveness in getting jobs or building a business entrepreneurship workshop that still has prospective business opportunities in the South Tangerang City area.
\end{abstract}

Keywords: unemployed high school/vocational school graduates, training, maintenance, motorbikes

\section{PENDAHULUAN}

Berdasarkan data BPS (2019), tercatat jumlah pengangguran secara nasional (2019) sebanyak 7,05 juta orang, meningkat dari Agustus 2018 yang hanya 7 juta orang. Dari jumlah pengangguran tersebut, tingkat pengangguran didominasi oleh lulusan SMK sebesar 10,42\%, selanjutnya lulusan SMA menempati peringkat kedua dengan persentase $7,92 \%$, diikuti diploma I/II/III 5,99\%, universitas 5,67\%, SMP 4,75\%, dan SD 2,41\% [1]. Sementara itu, jumlah pengangguran di Provinsi Banten tahun 2019 mencapai $8,11 \%$, menurun dari angka $8,52 \%$ pada tahun 2018. Pengangguran di Provinsi Banten juga didominasi oleh lulusan SMK yang menempati angka $13.03 \%$ dibanding lulusan pendidikan lain. Demikian juga, angka pengangguran di Kota Tangerang Selatan pada tahun 2019 tercatat 40 ribu yang juga didominasi oleh lulusan SMA dan SMK [2] .

Berdasarkan data tersebut, baik tingkat nasional, provinsi dan Kota Tangerang Selatan menunjukkan kecenderungan yang sama, bahwa lulusan SMA dan SMK mendominasi angka pengangguran. Hal ini tentunya ironis, khususnya lulusan SMK yang diharapkan dapat mengisi pekerjaan di berbagai industri, namun kenyataannya sebagian besar tidak terserap di pasar kerja. Pengangguran terjadi karena adanya ketidaksesuaian antara permintaan tenaga kerja dan penawaran tenaga kerja. Untuk itu, pemerintah perlu mengevaluasi pelaksanaan pendidikan di 
SMK agar lulusan dapat mengisi kebutuhan tenaga kerja di berbagai industri yang tersedia

Karang Taruna adalah organisasi sosial kemasyarakatan sebagai wadah dan sarana pengembangan setiap anggota masyarakat yang tumbuh dan berkembang atas dasar kesadaran dan tanggung jawab sosial dari, oleh dan untuk masyarakat terutama generasi muda di wilayah desa/kelurahan terutama bergerak di bidang usaha kesejahteraan sosial" [3].

Karang Taruna memiliki sasaran yang memfokuskan pada kesadaran dan tanggung jawab sosial dalam pelaksanaan pembangunan, sehingga dapat mewujudkan kesejahteraan sosial yang dapat dinikmati oleh seluruh masyarakat. Untuk mencapai sasaran tersebut, maka tugas pokok Karang Taruna adalah bersama-sama dengan pemerintah dan komponen masyarakat lainnya menanggulangi berbagai masalah pembangunan, sehingga peran dan kontribusi Karang Taruna dapat dirasakan oleh masyarakat di lingkungannya. Kondisi riil di masyarakat menunjukkan bahwa sebagian besar pemuda memiliki kompetensi yang rendah, sehingga cenderung menjadi pengangguran dan tidak mampu menciptakan lapangan kerja sendiri [4].

Berkaitan dengan kondisi tersebut, maka Karang Taruna sebagai salah satu organisasi penggerak pembangunan pemuda di tingkat desa/kelurahan perlu mengambil peran guna membantu dalam mengatasi berbagai masalah yang dihadapi pemuda terutama yang terkait dengan upaya untuk menciptakan pemuda produktif.

Keberadaan kendaraan bermotor roda roda (sepeda motor) sebagai alat transportasi mengalami pertumbuhan yang signifikan setiap tahunnya. Berdasarkan data BPS Provinsi Banten 2015-2019 (Tabel 1), jumlah kendaraan sepeda motor di Kota Tangerang terjadi peningkatan sekitar 16\%, sedangkan di wilayah Kecamatan Setu, Kota Tangerang Selatan jumlah kendaraan sepeda motor di tahun 2015 ada sebanyak 81.030 unit [6]. Jika diasumsikan peningkatan hingga tahun 2019 adalah 16\% maka di tahun 2019 jumlah sepeda motor di wilayah Kecamatan Setu, Kota Tangerang Selatan ada sebanyak 93.994 unit. Melihat kondisi tersebut, potensi dan peluang bisnis jasa pemeliharaan kendaraan sepeda motor menjadi sangat prospektif.

Tabel 1. Data jumlah kendaraan sepeda motor di Provinsi Banten 2015 - 2019. [5]

\begin{tabular}{lrrrrr}
\hline \multicolumn{1}{c}{ Kabupaten/Kota } & \multicolumn{5}{c}{ Sepeda Motor } \\
& \multicolumn{1}{c}{$\mathbf{2 0 1 5}$} & \multicolumn{1}{c}{$\mathbf{2 0 1 6}$} & \multicolumn{1}{c}{$\mathbf{2 0 1 7}$} & \multicolumn{1}{c}{$\mathbf{2 0 1 8}$} & \multicolumn{1}{c}{$\mathbf{2 0 1 9}$} \\
\hline Kab Pandeglang & 216112 & 200385 & 215708 & 195102 & 213342 \\
Kab Lebak & 232739 & 234383 & 253224 & 234962 & 259097 \\
Kab Tangerang & 1233878 & 1108514 & 1224583 & 1216558 & 1339870 \\
Kab Serang & 306070 & 329751 & 368806 & 380143 & 416249 \\
Kota Tangerang & 958062 & 886569 & 954431 & 1026993 & 1114765 \\
Kota Cilegon & 206992 & 227712 & 242801 & 172008 & 184410 \\
Kota Serang & 202278 & 187040 & 208750 & 186521 & 202846 \\
Kota Tangerang Selatan & 577126 & 598796 & 648493 & 698867 & 764939 \\
Provinsi Banten & 3933257 & 3773150 & 4116796 & 4111154 & 4495518 \\
\hline
\end{tabular}

Pemberdayaan adalah upaya meningkatkan kemampuan dan kemandirian masyarakat dalam memenuhi kebutuhan pokok dan memecahkan masalah mereka secara mandiri dengan mengembangkan berbagai potensi yang dimilikinya [7]. Pemberdayaan merupakan strategi dalam paradigma pembangunan yang berpusat pada masyarakat (people centered development). Pendekatan ini menyadari pentingnya kapasitas masyarakat untuk meningkatkan kemandirian dan kekuatan internal melalui kesanggupan untuk melakukan control internal atas sumberdaya melalui retribusi, modal dan kepemilikan [8]. Selain itu, pemberdayaan merupakan sebuah proses yang menekankan bahwa orang memperoleh keterampilan, pengetahuan, dan kekuasaan/Penguasaan yang cukup mempengaruhi kehidupannya dan kehidupan orang lain yang menjadi perhatiannya [9].

Sebagai ikhtiar untuk mengatasi permasalahan pengangguran, terutama pemuda lulusan SMA/SMA di Kota Tangerang Selatan, Program Studi Teknik Mesin Otomotif, Institut Teknologi Indonesia bekerjasama dengan Pemuda Karang Taruna Kelurahan Setu, Kecamatan Setu, Kota Tangerang Selatan mengadakan kegiatan pelatihan pemeliharaan/ servis kendaraan sepeda motor. Sasaran peserta pelatihan adalah pemberdayaan pemuda anggota Karang Taruna di Kelurahan Setu, Kota tengerangn Selatan terutama yang belum mendapatkan pekerjaan atau dan memiliki ketrampilan dalam perawatan atau servis sepeda motor. Dari kegiatan pelatihan ini diharapkan dapat meningkatkan ketrampilan pemuda dalam pemeliharaan/servis kendaraan sepeda motor, sehingga dapat meningkatkan daya saing dalam mendapatkan pekerjaan atau membangun bisnis bengkel sepeda motor.

\section{METODE}

Proses pelatihan dilakukan di Kampus Institut Teknologi Indonesia (ITI), Kelurahan Setu, Kota Tangerang Selatan selama 4 hari. Tahapan proses pelatihan perawatan dan servis sepeda motor dapat dilihat pada Gambar 1.

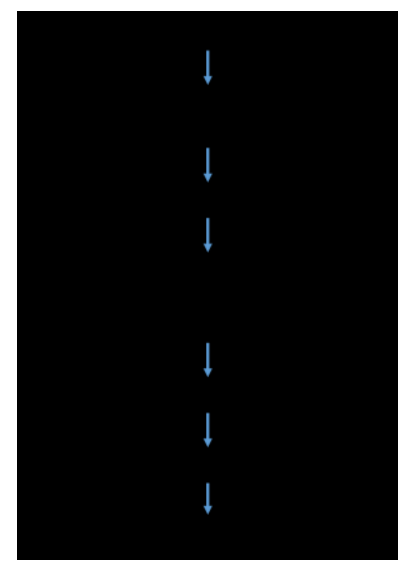

Gambar 1. Diagram alir pelatihan perawatan dan servis sepeda motor. 
Proses pelatihan diawali dengan melakukan survey dan pendataan pemuda Karang Taruna berdasarkan data yang diperoleh dari ketua Karang Taruna dan diketahui oleh Kelurahan Setu. Setelah data diperoleh, kemudian dilakukan seleksi dan pemilihan anggota pelatihan berdasarkan kebutuhan dan persayaratan yang telah dibuat oleh tim pelatihan dan terpilih sebanyak 7 orang..

Sosialisasi dilakukan kepada para anggota pelatihan yang terpilih terkait dengan tujuan dan manfaat dari pelatihan perawatan dan servis ringan sepeda motor yang di laksanakan di Laboratorium Teknik Mesin Otomotif Diploma 3, ITI.

Proses teknis selanjutnya, tim melakukan persiapan untuk pelaksaanan pelatihan seperti menyiapkan modul dan jadwal pelatihan, peralatan, bahan peraga dan alat-alat pendukung lainnya. Materi pelatihan dibagi menjadi 2 bagian yaitu teori dan praktek dengan bobot $20 \%$ teori dan $80 \%$ praktek. Teori yang diberikan terkait dengan pengetahuan material teknik, bahan bakar dan manajemen bengkel dan perawatan sepeda motor dan servis, praktik perawatan dan servis. Setelah pembekalan teori selesai, para peserta pelatihan kemudian melakukan praktek lapangan di laboratorium otomotif mengenai perawatan dan servis sepeda motor. Selama proses pelatihan, para peserta pelatihan di monitoring dan di evaluasi (dengan memberikan kasus di lapangan dan kuisioner) dan hasilnya kemudian dibahas dan dilaporkan kepada lembaga terkait.

\section{HASIL DAN PEMBAHASAN}

Pembahasan dilakukan berdasarkan data yang diperoleh dan dikumpulkan selama proses pelatihan berlangsung. Data yang dikumpulkan berdasarkan data pengamatan kepada para peserta pelatihan terhadap kasus yang diberikan selama mengikuti pelajaran teori dikelas dan praktik perawatan dan servis sepeda motor di laboratorium otomotif. Data lain yang akan digunakan dalam pembahasan ini adalah berdasarkan kuisioner yang diberikan kepada peserta pelatihan terhadap kepuasan selama proses pelatihhan berlangsung.

Berdasakan pengamatan langsung selama proses pelatihan, para peserta pelatihan terlihat sangat antusias. Hal ini dapat dilihat pada kegiatan di hari pertama yaitu pemberian teori di kelas otomotif mengenai pengetahuan bahan bakar dan pengantar kendaraan sepeda motor. Antusiasme dapat dilihat dari keseriusan peserta dalam mengikuti pelatihan dan terjadinya interaksi yang aktif antara peserta dan instruktur. Antusias peserta juga terlihat dihari kedua disaat pemberian materi mengenai material teknik yang digunakan pada kendaraan sepeda motor (gambar 2) di laboratorium otomotif ITI. Peserta pelatih diberikan teori dan pertanyaan atau kasus selama proses pelatihan berlangsung.

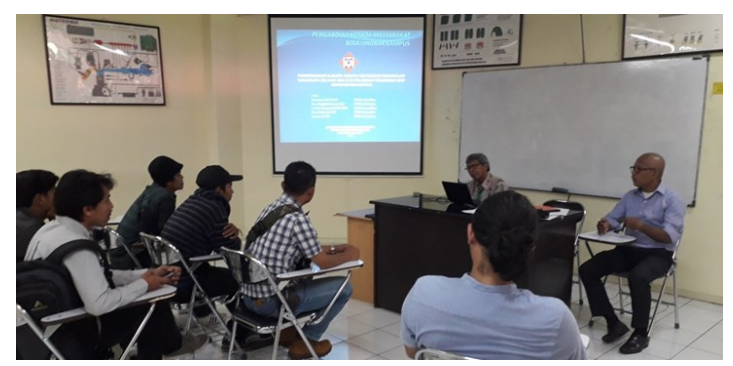

Gambar 1. Kegiatan hari pertama, pemberian materi bahan bakar dan pengantar kendaraan sepeda motor.

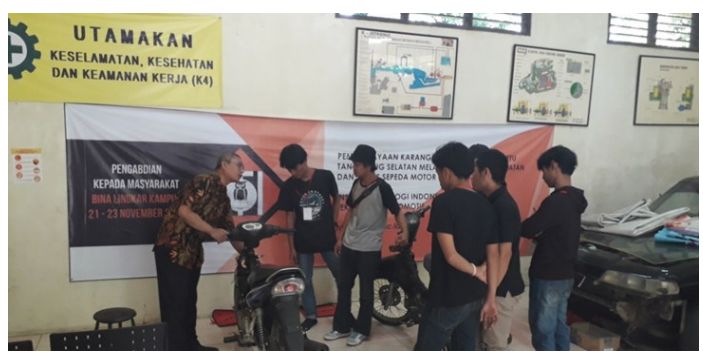

Gambar 2. Kegiatan hari kedua, pemberian materi pengantar material teknik kendaraan sepeda motor.

Gambar 3 memperlihatkan antusias peserta pelatihan selama pratik perawatan dan servis sepeda motor. Para peserta pelatihan di bagi menjadi 2 kelompok. Pertama - tama para peserta diberikan alat peraga berupa sepeda motor dalam keadaan kondisi yang tidak bisa beroperasi. Selanjutnya para peserta pelatihan diberikan informasi masalah yang terjadi pada sepeda motor dan para peserta pelatihan diminta untuk menyelesaikan permasalahan tersebut.

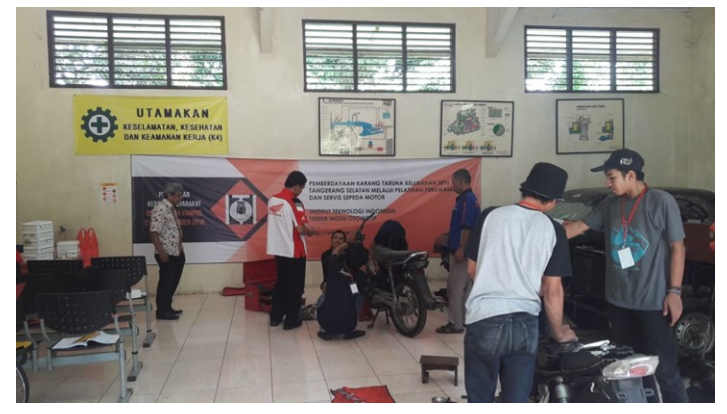

Gambar 3. Kegiatan hari ketiga, Praktik perawatan dan servis kendaraan sepeda motor.

Setelah rangkaian proses pelatihan selesai dilaksanakan, para peserta pelatihan diberikan kuisioner sebelum acara penutupan yang dihadiri oleh Ketua Karang Taruna Kelurahan Setu (gambar 4). Kuisioner diberikan langsug secara 
lisan pada masing - masing peserta. Berdasarkan hasil tersebut seluruh peserta pelatihan menyatakan bahwa pelatihan yang diterima sesuai harapan. Selain itu, para peserta pelatihan dapat menerima informasi dengan baik dan instrukturnya dapat membantu menyelesaikan masalah berkaitan dengan materi pelatihan. Metode mengajar instruktur membantu proses belajar sehingga pengetahuan para peserta pelatihan menjadi bertambah setelah mengikuti pelatihan dengan didukung fasilitas pelatihan yang memadai dan materi dan buku panduan pelatihan dapat dipelajari dengan baik.

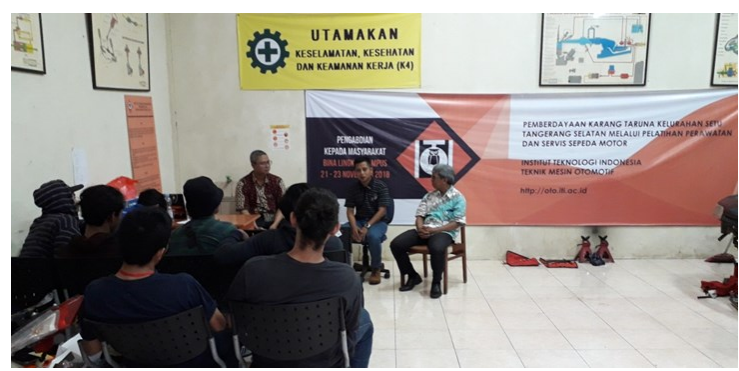

Gambar 4. Kegiatan hari terakhir, pemberian kuisioner dan penutupan proses pelatihan.

Berdasarkan proses pelatihan perawatan dan servis sepeda motor yang telah dilakukan di laboratoium otomotif ITI, para peserta pelatihan menjadi terampil dalam perawatan dan servis sepeda motor. Disisi lain, para peserta pelatihan juga memberikan masukan berupa waktu pelaksanaan pelatihan yang menurut mereka masih kurang panjang. Namun demikian, para peserta pelatihan merasa puas dan menyatakn kesiapannya untuk membuka bengkel baru dengan pendampingan oleh instruktur dari Prodi Otomotif-ITI.

\section{OUTCOME}

Secara umum luaran dari kegiatan ini diharapkan dapat mengatasi permasalahan pengangguran, terutama pemuda lulusan SMA/SMA di Kota Tangerang Selatan. Secara khusus luaran yang diharpkan dari pelatihan ini adalah meningkatkan pengetahuan dan keterampilan terkait dengan teknis pemeliharaan, servis ringan serta manajemen dan pengelolaan bengkel untuk karang taruna di Kelurahan Setu Kecamatan Setu, Kota Tangerang Selatan, sehingga dapat meningkatkan daya saing dalam mendapatkan pekerjaan atau membangun bisnis bengkel sepeda motor.

\section{KESIMPULAN}

Berdasarkan hasil kegiatan selama 4 (empat) hari dan diikuti oleh 7 orang peserta pelatihan, para peserta pelatihan cukup menguasai pengetahuan dan praktek perawatan dan servis kendaraan sepeda motor. Melalui kegiatan pelatihan ini diharapkan peserta memiliki kepercayaan diri dan daya saing dalam mendapatkan pekerjaan atau membangun kewirausahaan bisnis bengkel yang masih memiliki peluang bisnis yang prospektif di wilayah Kota Tangerang Selatan.

\section{UCAPAN TERIMA KASIH}

Terima kasih kepada semua pihak yang telah membantu dalam program bina lingkar kampus ini sehingga semua dapat berjalan dengan baik. Terima kasih kepada pihak Kelurahan Setu yang telah menfasilitasi dalam bentuk koordinasi dengan Karang Taruna Kelurahan Setu - Tangsel. Terima kasih juga kepada Lembaga Pengabdian dan Pengembangan Masyarakat Institut Teknologi Indonesia (LP2M ITI) yang telah memberikan support baik dalam bentuk materi maupun non materi.

\section{REFERENSI}

[1] Badan Pusat Statistik, 2019. Angka Pengangguran Naik Jadi 7,05 Juta Orang per Agustus 2019.

[2] Badan Pusat Statistik, Provinsi Banten 2019. Pengangguran di Kota Tangerang Didominasi Lulusan SMA.

[3] Citra Gaffara Taqwarahmah, Bagus Riyono, Diana Setiyawati, Jurnal Ketahanan Nasional, Vol. 23, No 1, April 2017: 37-48.

[4] Suprayoga, Andi Iswoyo, Ramon Syahrial (2016). Model Pemberdayaan Karang taruna di Kecamatan Cerme, Kabupaten Gresik. Asian Journal of Innovation and Entrepreneurship, Vol. 01 (02), 134-147.

[5] Badan Pusat Statistik Provinsi Banten 20152019.

[6] Review Renstra Tahun 2016 - 2021, Dinas Perhubungan Kota Tangerang Selatan.

[7] Direktorat Jendral Pemberdayaan Sosial. 2005. Pedoman Manajemen Organisasi Sosial. Depsos RI, Jakarta.

[8] Sumardjo dan Saharudin. 2006. MetodeMetode Partisipatif dalam Pengembangan Masyarakat. Sekolah Pascasarjana IPB, Bogor.

[9] Atma Ras, Pemberdayaan Masyarakat Sebagai Upaya Pengentasan Kemiskinan, SOCIUS VOLUME XIV, Oktober-Desember 2013. 